Review

\title{
Radiobiology and Reproduction-What Can We Learn from Mammalian Females?
}

\section{Aurora Ruiz-Herrera ${ }^{1,2, *}$, Francisca Garcia ${ }^{3}$ and Montserrat Garcia-Caldés ${ }^{1,2, *}$}

1 Departament de Biologia Cellular, Fisiologia i Immunologia, Universitat Autònoma de Barcelona, Campus UAB, 08193, Cerdanyola del Vallès, Barcelona, Spain

2 Institut de Biotecnologia i Biomedicina (IBB), Campus UAB, 08193, Cerdanyola del Vallès, Barcelona, Spain

3 Unitat de Cultius Cellulars, Servei de Cultius Cellulars, Producció d'Anticossos i Citometria (SCAC), Universitat Autònoma de Barcelona, Campus UAB, 08193, Cerdanyola del Vallès, Barcelona, Spain; E-Mail: francisca.garcia@uab.cat

* Authors to whom correspondence should be addressed; E-Mails: aurora.ruizherrera@uab.cat (A.R.-H.); montserrat.garcia.caldes@uab.cat (M.G.-C.); Tel.: +34-93-581-2051 (A.R.-H.); Fax: +34-93-581-3357 (A.R.-H.).

Received: 20 June 2012; in revised form: 9 August 2012 / Accepted: 13 August 2012 /

Published: 27 August 2012

\begin{abstract}
Ionizing radiation damages DNA and induces mutations as well as chromosomal reorganizations. Although radiotherapy increases survival among cancer patients, this treatment does not come without secondary effects, among which the most problematic is gonadal dysfunction, especially in women. Even more, if radio-induced DNA damage occurs in germ cells during spermatogenesis and/or oogenesis, they can produce chromosomal reorganizations associated with meiosis malfunction, abortions, as well as hereditary effects. However, most of our current knowledge of ionizing radiation genotoxic effects is derived from in vitro studies performed in somatic cells and there are only some experimental data that shed light on how germ cells work when affected by DNA alterations produced by ionizing radiation. In addition, these few data are often related to mammalian males, making it difficult to extrapolate the results to females. Here, we review the current knowledge of radiobiology and reproduction, paying attention to mammalian females. In order to do that, we will navigate across the female meiotic/reproductive cycle/life taking into account the radiation-induced genotoxic effects analysis and animal models used, published in recent decades.
\end{abstract}


Keywords: meiosis; oocytes; fertility; ionizing irradiation effects; radiation-sensitivity; DSBs, genome instability

\section{Introduction}

Ionizing radiation (IR) damages DNA and induces genetic mutations as well as chromosomal reorganizations, that result in single-strand breaks (SSBs) and/or double-strand breaks (DSBs). DSBs constitute a particular hazard to cells given that, if persistent, they can lead to carcinogenesis. In mammalian cells, different pathways in response to DNA damage maintain genome stability controlling either the cell cycle or the repair of the damage itself. These mechanisms are known as the DNA damage response (DDR), which includes several pathways that are selectively activated depending on the genetic insult (reviewed in [1]). Especially relevant to radiobiology are the mechanisms that detect and repair SSBs and DSBs. The DDR can be divided into a series of distinct pathways depending on the type of DNA lesion they process (review in [1]). SSBs are repaired basically by the base excision repair (BER) mechanism with the implication of several proteins such as PARP1, XRCC1 or LIGASE 3. DSBs, on the other hand, are repaired through two main mechanisms: (i) homologous recombination (HR), which requires large regions of homology, and (ii) non-homologous end joining (NHEJ) [2]. NHEJ is active preferentially during the $G_{1}$ to early $S$ phase of the cell cycle whereas HR takes place in late $S$ and $G_{2}$ phases. Both mechanisms are implicated in the reparation of radio-induced DSBs given that mammalian cells defective in proteins involved in these processes (i.e., DNA-PKcs or RAD54) have been shown to be hypersensitive to ionizing radiations [3-5].

Most of our current knowledge of ionizing-radiation genotoxic effects comes from in vitro studies performed in somatic cells. But if radio-induced genetic insults occur in germ cells, during spermatogenesis and/or oogenesis, chromosomal reorganizations can appear, and it is well known that they are associated with meiosis malfunction and abortions as well as hereditary effects. Therefore, our need for radiobiology studies in the germ line is beyond question. Especially relevant for reproductive studies are the proteins implicated in the recognition and repair of DSBs by homologous recombination (HR) that occurs during the meiotic prophase I. At this stage, HR is essential for the proper disjunction of homologous chromosomes, which is triggered by programmed DSBs, the formation of which is catalyzed by the DNA topoisomerase-II-related protein Spo11 [6]. In addition to Spo11, DSB formation requires other proteins [7]. The broken ends are processed by 5' to 3' degradation, and the resulting 3' single-stranded ends invade the homologous chromosome, which results in the formation of a heteroduplex. The resulting single stranded DNA (ssDNA) forms the substrate for subsequent strand invasion, which is catalyzed by the two recA homologs Rad51 and Dmcl. Some proteins involved in the recombination process have been identified in the last few years. The replication protein A (RPA) is a component of the transitional meiotic nodules [8] while MLH1 is a marker of crossovers (COs) events [9]. The meiotic prophase I is under the regulation of checkpoint systems that recognize those chromosomes that remain unpaired at the pachytene stage and lead to its silencing through the recruitment of proteins such as BRCA1 and ATR [10]. Therefore, germ cells, depending on the cell cycle, would contain detectable levels of different proteins involved in the 
recognition and repair of DSBs by HR (ATR, ATM, RAD51, BRCA1, BRCA2, MSH2 and MSH3, among others). The presence of these proteins might make meiotic cells less sensitive to the DSBs induced by IR than other cell types. However, at this stage, it is not known how these proteins interplay when radio-induced genetic insults occur during the meiotic prophase I.

Radiotherapy has tremendously increased survival among cancer patients. However, this treatment does not come without secondary effects, among which the most problematic one refers to gonadal dysfunction, especially in women $[11,12]$. Furthermore, although now it is possible to estimate, based on mathematical models, the dose of fractionated radiotherapy (Gy) at which premature ovarian failure occurs immediately after treatment with IR [12], our knowledge of the genotoxic effects is still very poor. Therefore, wider knowledge of the genotoxic and gonadal effects of ionizing radiation upon the female function and the possibility of treatment or prevention of the ovarian lesion would mitigate some of the consequences of these therapies in cancer patients. There are recent reports that suggest a link between resistance to radiotherapy and altered DDR activity in cancer stem-cells and tumor-initiating cells [13], so new targets for therapy can be developed in the near future. With this big picture in mind, here we review the current knowledge of radiobiology and reproduction, paying special attention to mammalian females. We will navigate across the female meiotic cycle, focusing on the radiation-induced genotoxic effects analysis and animal models used in the last three decades, analyzing what we can learn from mammalian females.

\section{Female Gametogenesis: Its Complexity and Uniqueness}

Gametes are produced during gametogenesis through a meiotic program, which involves two successive rounds of cell division (MI and MII) that follow a single round of DNA replication. In mammals, oogenesis is a complex physiological process that differs from spermatogenesis in several ways, such as gametes morphology and differentiation, place and timing, among others. While spermatogenesis produces a relatively small motile gamete, the oocyte is a bigger cell that contains all the materials needed to initiate and maintain metabolism and development. Whereas spermatogenesis occurs during the whole active life of an adult, thus males have the ability to produce spermatocytes continuously, oogenesis initiates early in development, becomes arrested at the moment of birth and resumes at the puberty stage (Figure 1). This intrinsic complexity has, as a result, meant that female mutation data are scarce in the literature. From the few data available the general view that can be extracted is the existence of gender differences in the induction of chromosomal aberrations and gene mutations [14,15].

In humans, around the 22nd embryonic day, primordial germ cells migrate to the embryonic gonads. Since then and until the 6th month of pregnancy, germ cells enter meiosis, complete meiotic prophase I, and arrest at the dictiotene stage until puberty begins. At the moment of birth, the ovaries of a human female contain approximately $2 \times 10^{6}$ immature, primordial follicles [16], each of which contains an immature primary oocyte. In mice, two-thirds of the oocytes enter apoptosis after birth, while the remaining oocytes separate from the cysts into single cells that become surrounded by granulose cells to form primordial follicles [17]. In fact, it has been reported that, in the mouse C57BL/6 strain, the mean number of primordial follicle numbers and oocytes ( \pm s.e.m.) in Day 1 after birth (a.b.) ovaries was 7,924 $\pm 1,564$ and declined significantly to $1,987 \pm 203$ in Day 7 a.b. ovaries 
due to programmed cell death [18]. Then, primordial follicles are gradually recruited to primary and secondary pre-antral follicles, a process known as folliculogenesis. During this stage, both oocytes and granulose cells grow and mature in a synchronic way, establishing cell communications and, therefore, they can be considered as a functional syncytium. After puberty, with the first menstruation, a number of follicles enter into a growth pattern that will end in cell death or in ovulation (the process where the oocyte leaves the follicle). In humans, folliculogenesis lasts for approximately 375 days, being a process that operates regularly. This means that at any time of the female reproductive life the ovary contains follicles in all stages of development, and ends when a mature oocyte departs from the ovulatory follicle during ovulation. Roughly, these stages include, following a sequence in time: primordial follicles, pre-antral follicles, antral follicles (also known as pre-ovulatory follicles) and ovulatory follicles (Figure 1). While the follicles are growing, the oocytes I grow and mature in parallel, which is a complex phenomenon that includes both nuclear and cytoplasm maturation. While the nuclear maturation implies that the oocyte progresses from diplonema to metaphase II (MII) stage, there are essential transformations at the cytoplasmatic level that prepare the cell to support fertilization and early embryonic development. Only when the oocyte is competent, is it released and ready for fertilization. Immediately after fertilization, the zygote (the fertilized egg) enters into a series of rapid mitotic divisions (cleavage) that ends with the formation of the blastocyst, which hatches from the zona pellucida and is ready for implantation. This pre-implantational period takes between 5-6 days in mice, and a little bit longer in humans. After implantation, organogenesis (the production of tissues and organs)/fetogenesis begins a process that ends at the moment of birth.

In any mammalian female at the moment of birth, immature oocytes (non-growing oocytes I, growing oocytes I and grown oocytes) are arrested at the dictiotene prophase I stage and can form primordial follicles, primary and/or multilaminar follicles or pre-antral follicles. During maturation, the oocyte is still arrested at diakinesi but granulosa cells grow and interact with the growing oocytes, gradually forming pre-antral follicles (Figure 1). The literature is sometimes misleading with the use of these terms, but we can consider that antral follicles (also known as pre-ovulatory follicles) contain maturing and mature oocytes I, whereas ovulatory follicles have mature and competent oocytes at the MII stage. In this sense, it is important to bear in mind that oocytes are blocked in prophase I during long periods of time. In humans, for example, some oocytes will be maintained in meiotic prophase I for many years. The challenging goal in this context is to conserve an oocyte without any defect to proceed to cycle. Also, during this long period, oocytes have high probabilities to suffer genetic insults, which, if repaired incorrectly, can induce permanent aberrations that can be propagated to the progeny. Evidence indicates that oocyte radiation-sensitivity depends on its developmental stage and its relation with folliculogenesis. So, this nomenclature is important, given that most of the irradiation studies, conducted mainly in rodents, have been focused on immature and mature/pre-ovulatory oocytes (Figure 1). 
Figure 1. Schematic representation of the radiation experiments in vivo performed in mammalian females considering the folliculogenesis/oocyte stage, the irradiation dose and the parameters analyzed.

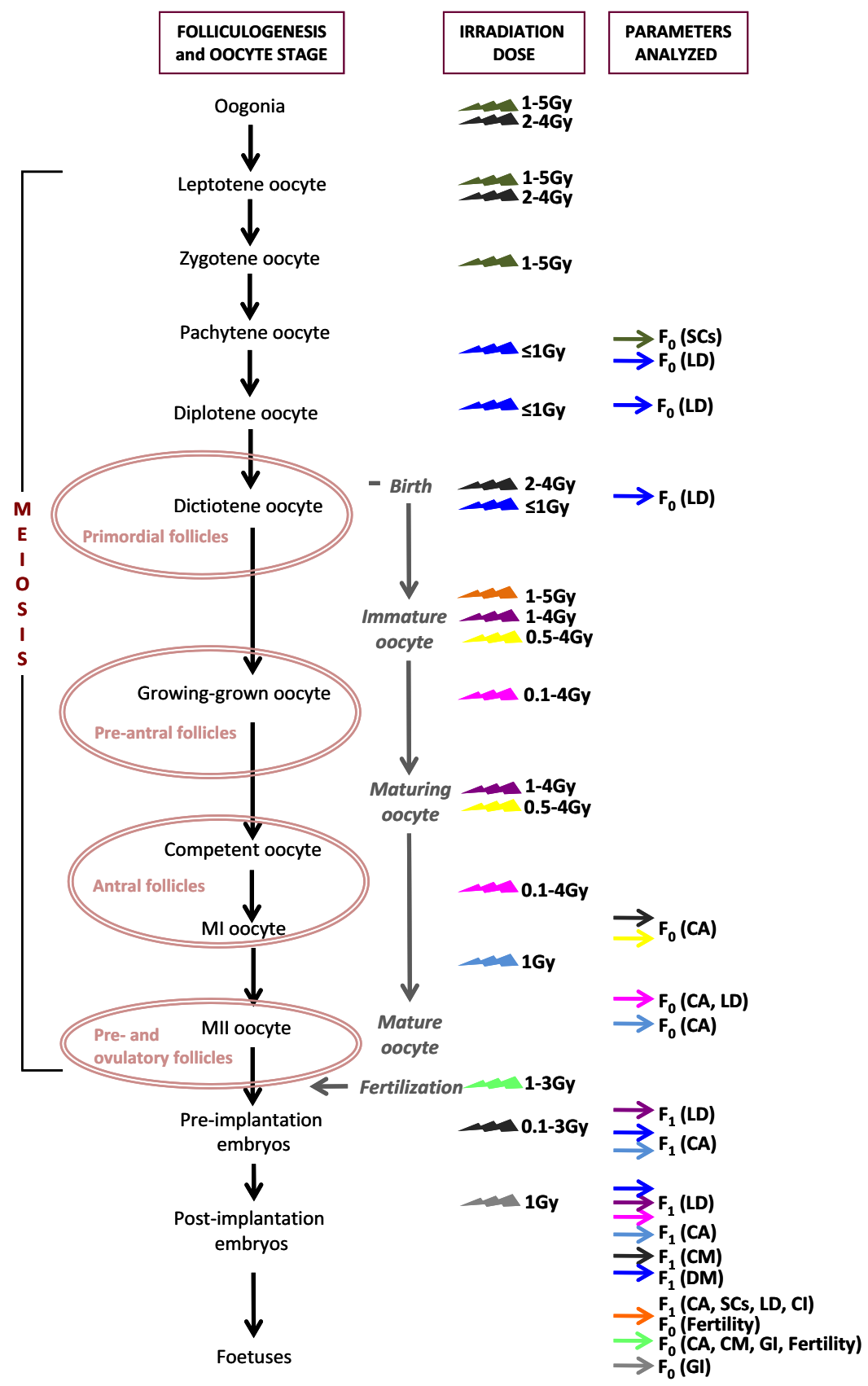

All phases of oogenesis are represented (from oogonia to ovulatory follicles) as well as earlier stages of embryo development (see text for details regarding female gametogenesis). The figure represents the moment of irradiation ( $)$ and the stage where the parameters were analyzed (arrows). Different colors indicate different studies reported: deep green [19-21], light green [22-26], black [27-32], deep blue [33-36], light blue [37,38], orange [39-43], purple [44], yellow [45,46], pink [47-50], and grey [51]. For the parameters studied, $\mathrm{F}_{0}$ indicates that the parameter has been analyzed in the irradiated female, whereas $\mathrm{F}_{1}$ indicates that the parameter has been analyzed in the progeny of the irradiated female. Legend-Gy: irradiation dose (Grey), CA: chromosomal aberrations, GI: genome instability, CM: congenital malformations, DM: developmental malformations, LD: lethal dose, SC: synaptonemal complex. 
Mutational studies on the effects of ionizing irradiation in somatic cells have revealed that genotoxicity depends not only on the irradiation dose, but also on the cell type and cycle. Such studies have contributed enormously to our knowledge on how IR induces mutations and how they are repaired [1]. But if our goal is to study how radio-induced genetic insults affect reproduction and/or how they are propagated to the offspring, we need direct observations of the germ line. At this point, and despite its importance, the study of the genotoxic effect of IR on the germ line faces numerous methodological challenges, such as the intrinsic nature of oogenesis, animal manipulation, time-consuming protocols and the lack of an in vitro ad hoc methodology. The intrinsic nature of female gametogenesis, long periods (as in years) make it possible that errors induced by genotoxic agents occur during meiosis compromise fertility, the viability of the embryos and, eventually, induce genetic abnormalities that can be propagated in the offspring (so-called trans-generational effects). As stated earlier, meiotic prophase I occurs during the prenatal process of oocyte formation. This first stage of meiosis begins in the embryo and stops at birth, reactivating the signal to resume meiosis at the puberty. This complexity also makes the genotoxic effect of ionizing radiation difficult to evaluate in the female germ-line. Not all cells are equally sensitive to radiation damage; cells that divide rapidly and/or are relatively non-specialized, tend to show effects at lower doses of radiation than do those that have a longer cell cycle. It has been reported that, during oogenesis, the sensitivity of oocytes to genotoxic factors depends on the meiotic phase and the stage of folliculogenesis $[52,53]$.

Another level of complexity is animal manipulation for in vivo experiments and the difficulty of extrapolating results among different species models. It has been suggested, for example, that the guinea pig is the best model for the study of radiation-induced genotoxic effects in the female germ-line [27] but as we will see herein, that would depend on the parameter analyzed (Table 1). Therefore, for any radiobiology study, it is of relevant importance to consider the cell type, age and/or developmental stage at the moment of the irradiation and the parameter considered, as well as the model species, in order to understand the reproductive implications of radiation damage.

Table 1. Summary of the results of genotoxic effects of ionizing irradiation on experimental models.

\begin{tabular}{|c|c|c|c|c|}
\hline $\begin{array}{l}\text { Species } \\
\text { studied }\end{array}$ & $\begin{array}{l}\text { Meiotic/Oocyte stage and } \\
\text { irradiation dose }\end{array}$ & Parameters analyzed & Summary of results & Reference \\
\hline mouse & $\begin{array}{l}\text { Adult females } \\
63 \text { rads }\end{array}$ & $\begin{array}{l}\text { Locus-specific mutation at } \\
\mathrm{F}_{1}\end{array}$ & $(-)$ & {$[54]$} \\
\hline mouse & $\begin{array}{l}\text { Ovaries } \\
0.15 \mathrm{~Gy}\end{array}$ & $\begin{array}{l}\text { Cell killing } \\
\text { Fertility }\end{array}$ & $\begin{array}{l}\mathrm{LD}_{50}: 0.15 \mathrm{~Gy} \\
\text { Maximum } 4 \text { litters/female; } \\
\text { Early follicles RS > Larger follicles RS }\end{array}$ & {$[16]$} \\
\hline mouse & $\begin{array}{l}\text { Mature and immature } \\
\text { oocytes } \\
100-400 \text { rads }\end{array}$ & $\begin{array}{l}\text { Dominant lethality (pre and } \\
\text { post-implantation } \\
\text { mortality) }\end{array}$ & RS species and oocyte stage-dependent & {$[44]$} \\
\hline mouse & $\begin{array}{l}\text { Pre-ovulatory oocytes } \\
22-600 \text { rads }\end{array}$ & $\begin{array}{l}\text { Chromosomal aberrations } \\
\text { at MII }\end{array}$ & $\begin{array}{l}(+) \\
\text { Mature oocyte RS > Immature oocyte } \\
\text { RS }\end{array}$ & {$[37,38]$} \\
\hline
\end{tabular}


Table 1. Cont.

\begin{tabular}{|c|c|c|c|c|}
\hline $\begin{array}{l}\text { Species } \\
\text { studied }\end{array}$ & $\begin{array}{l}\text { Meiotic/Oocyte stage and } \\
\text { irradiation dose }\end{array}$ & Parameters analyzed & Summary of results & Reference \\
\hline & $\begin{array}{l}\text { Adult females } \\
0.22,0.66,2 \text { and } 6 \mathrm{~Gy}\end{array}$ & $\begin{array}{l}\text { Chromosomal aberrations at: } \\
\text { - MII } \\
\text { - 2-cell embryo } \\
\text { - } 13.5 \text {-day embryo }\end{array}$ & $\begin{array}{l}(+) \\
(+) \\
(-)\end{array}$ & \\
\hline mouse & $\begin{array}{l}\text { Mature and immature oocytes } \\
50-400 \text { rads }\end{array}$ & $\begin{array}{l}\text { Chromosomal aberrations at } \\
\text { MI }\end{array}$ & $\begin{array}{l}\text { Mature oocyte RS > Immature oocyte } \\
\text { RS }\end{array}$ & {$[46]$} \\
\hline mouse & $\begin{array}{l}\text { Immature oocytes } \\
400 \text { rads }\end{array}$ & $\begin{array}{l}\text { Chromosomal aberrations at } \\
\text { dictionema }\end{array}$ & $(-)$ & {$[55]$} \\
\hline mouse & $\begin{array}{l}\text { Pre-ovulatory oocytes } \\
0.05-0.80 \text { Gy }\end{array}$ & $\begin{array}{l}\text { Chromosomal non- } \\
\text { disjunction at MI }\end{array}$ & $(+)$ At higher dose & {$[56]$} \\
\hline mouse & $\begin{array}{l}\text { Adult females } \\
108-504 \text { rads }\end{array}$ & $\begin{array}{l}\text { Structural chromosome } \\
\text { aberrations at MII } \\
\text { Dominant lethality } \\
\text { Developmental } \\
\text { malformations }\end{array}$ & $\begin{array}{l}(+) \\
(+) \\
\text { Immature oocyte RS > Mature oocyte } \\
\text { RS }\end{array}$ & {$[57]$} \\
\hline mouse & $\begin{array}{l}\text { Juvenile mice } \\
6 \text { and } 7 \text { rads }\end{array}$ & Primordial oocyte killing & $\mathrm{LD}_{50}: 6-7$ rads & {$[58]$} \\
\hline mouse & $\begin{array}{l}\text { Oocytes at dictionema } \\
100-600 \mathrm{cGy}\end{array}$ & $\begin{array}{l}\text { Chromosomal aberrations at } \\
\text { one-cell embryos }\end{array}$ & $(+)$ & {$[47]$} \\
\hline mouse & $\begin{array}{l}\text { Pre-ovulatory oocytes } \\
\leq 100 \text { cGy }\end{array}$ & $\begin{array}{l}\text { Chromosomal aberrations at } \\
\text { MI }\end{array}$ & $(+)$ & [48] \\
\hline mouse & $\begin{array}{l}\text { Zygote stage } \\
2 \mathrm{~Gy}\end{array}$ & $\begin{array}{l}\mathrm{F}_{1} \text { chromosomal aberrations } \\
\text { and micronuclei }\end{array}$ & $(+/-)$ & {$[25]$} \\
\hline mouse & $\begin{array}{l}\text { Immature oocytes } \\
0.1 \text { and } 0.2 \text { Gy }\end{array}$ & $\begin{array}{l}\text { Chromosomal aberrations at } \\
\text { MII }\end{array}$ & $(+)$ & {$[50]$} \\
\hline mouse & $\begin{array}{l}\text { Fetal oocytes at } 14,16 \text {, and } 17 \\
\text { days of gestation } \\
2 \text { Gy }\end{array}$ & SC anomalies at pachynema & Fragmentation stage-dependent & {$[21]$} \\
\hline mouse & $\begin{array}{l}\text { Pre-implantation stage } \\
\leq 3 \text { Gy } \\
\text { Oocytes within 1-4 weeks } \\
\text { before ovulation } \\
2 \text { and } 3 \text { Gy }\end{array}$ & $\begin{array}{l}\text { Developmental } \\
\text { malformations } \\
\text { Developmental } \\
\text { malformations }\end{array}$ & $\begin{array}{l}(+) \\
\mathrm{LD}_{100}: 0.5 \mathrm{~Gy} \\
(+)\end{array}$ & [31] \\
\hline mouse & $\begin{array}{l}\text { Pre-ovulatory oocytes } \\
1-4 \text { Gy }\end{array}$ & $\begin{array}{l}\text { Chromosomal aberrations at: } \\
\text { - MII } \\
\text { - pre-implantation stages } \\
\text { - post-implantation stages }\end{array}$ & $\begin{array}{l}(+) \\
(+) \\
(-)\end{array}$ & [49] \\
\hline mouse & $\begin{array}{l}\text { Pre-implantation stage }(2 \mathrm{~h} \text {, } \\
48 \mathrm{~h}, 72 \text { and } 96 \mathrm{~h} \\
\text { post-conception) } \\
0.1-2.5 \mathrm{~Gy}\end{array}$ & $\begin{array}{l}\text { Developmental } \\
\text { malformations and mortality }\end{array}$ & $\begin{array}{l}(+) \\
\text { RS irradiation stage-dependent }\end{array}$ & {$[32]$} \\
\hline mouse & $\begin{array}{l}\text { Female zygote stage } \\
1 \mathrm{~Gy}\end{array}$ & $\begin{array}{l}\text { Fertility alterations } \\
\text { F1 developmental } \\
\text { malformations }\end{array}$ & $\begin{array}{l}(+) \\
(+)\end{array}$ & {$[22]$} \\
\hline
\end{tabular}


Table 1. Cont.

\begin{tabular}{|c|c|c|c|c|}
\hline $\begin{array}{l}\text { Species } \\
\text { studied }\end{array}$ & $\begin{array}{l}\text { Meiotic/Oocyte stage and } \\
\text { irradiation dose }\end{array}$ & Parameters analyzed & Summary of results & Reference \\
\hline \multirow[t]{3}{*}{ mouse } & Female zygote stage & Fertility alterations & $(-)$ & {$[23,24]$} \\
\hline & 0.2 and 0.4 Gy & $\begin{array}{l}\mathrm{F}_{1} \text { developmental } \\
\text { malformations }\end{array}$ & $(-)$ & \\
\hline & & $\begin{array}{l}\text { Trans-generational } \\
\text { genomic instability } \\
\text { (chromosomal aberrations) }\end{array}$ & $(-)$ & \\
\hline \multirow[t]{4}{*}{ mouse } & $\begin{array}{l}\text { Pre-conception stage } \\
1,2.8 \text {, and } 3 \mathrm{~Gy}\end{array}$ & $\begin{array}{l}\text { Developmental } \\
\text { malformations }\end{array}$ & $(+)$ dose-dependent & {$[26]$} \\
\hline & $\begin{array}{l}\text { Zygote stage } \\
1,2.8 \text {, and } 3 \mathrm{~Gy}\end{array}$ & $\begin{array}{l}\text { Developmental } \\
\text { malformations }\end{array}$ & $(+)$ dose-dependent & \\
\hline & $\begin{array}{l}\text { Pre-implantation stage } \\
1,2.8 \text {, and } 3 \mathrm{~Gy}\end{array}$ & $\begin{array}{l}\text { Developmental } \\
\text { malformations }\end{array}$ & $(+)$ dose-dependent & \\
\hline & $\begin{array}{l}\text { Zygote } \\
500 \mathrm{mGy}, 1,000 \mathrm{mGy} \text { and } \\
2,000 \mathrm{mGy}\end{array}$ & $\begin{array}{l}\text { Trans-generational genome } \\
\text { instability (chromosomal } \\
\text { aberrations) }\end{array}$ & $(+)$ & \\
\hline mouse & $\begin{array}{l}\text { Post-implantation stage } \\
1 \text { Gy }\end{array}$ & $\begin{array}{l}\text { Trans-generational genome } \\
\text { instability (ESTR mutation } \\
\text { frequencies) }\end{array}$ & $(-)$ & [51] \\
\hline mouse & $\begin{array}{l}\text { Pre-conception stage } \\
0.5,1 \text { and } 2 \text { Gy }\end{array}$ & $\begin{array}{l}\text { Trans-generational genome } \\
\text { instability (polymorphism } \\
\text { of DNA fragments) }\end{array}$ & $(+)$ tissue-dependent & {$[59]$} \\
\hline mouse & $\begin{array}{l}\text { Adult female } \\
1 \mathrm{~Gy}\end{array}$ & $\begin{array}{l}\text { Transgenerational genome } \\
\text { instability (ESTR mutation } \\
\text { frequencies) }\end{array}$ & $(-)$ & [60] \\
\hline $\begin{array}{l}\text { golden } \\
\text { hamster }\end{array}$ & $\begin{array}{l}\text { Mature and immature } \\
\text { oocytes } \\
100-400 \text { rads }\end{array}$ & $\begin{array}{l}\text { Dominant lethality (pre and } \\
\text { post-implantation } \\
\text { mortality) }\end{array}$ & RS species and oocyte stage-dependent & [44] \\
\hline guinea pig & $\begin{array}{l}\text { Mature and immature } \\
\text { oocytes } \\
100-400 \text { rads }\end{array}$ & $\begin{array}{l}\text { Dominant lethality (pre and } \\
\text { post-implantation } \\
\text { mortality) }\end{array}$ & RS species and oocyte stage-dependent & [44] \\
\hline guinea pig & $\begin{array}{l}\text { Mature and immature } \\
\text { oocytes } \\
4 \text { Gy }\end{array}$ & $\begin{array}{l}\text { Dominant lethality } \\
\text { (embryo mortality) }\end{array}$ & $\begin{array}{l}\text { Mature oocyte RS > Immature oocyte } \\
\text { RS }\end{array}$ & [45] \\
\hline \multirow[t]{5}{*}{ guinea pig } & $\begin{array}{l}\text { Oogonia and oocytes at } \\
\text { leptonema } \\
2 \text { and } 4 \mathrm{~Gy}\end{array}$ & Fertility & $(-)$ & {$[27-30]$} \\
\hline & $\begin{array}{l}\text { Oocytes at birth and at } \\
\text { adulthood } \\
2 \text { and } 4 \text { Gy }\end{array}$ & $\begin{array}{l}\text { Cell-killing } \\
\text { Fertility }\end{array}$ & $\begin{array}{l}\text { LD50: } 4 \text { Gy } \\
(-)\end{array}$ & \\
\hline & $\begin{array}{l}\text { One-cell embryo stage } \\
10,50 \text { and } 100 \mathrm{cGy}\end{array}$ & $\begin{array}{l}\text { Developmental } \\
\text { malformations }\end{array}$ & $(+)$ & \\
\hline & Oocytes at birth & Chromosomal aberrations & Mature oocyte RS > Immature oocyte & \\
\hline & 1 and 2 Gy & at MI & $\begin{array}{l}\text { RS } \\
\text { Nearly mature guinea pig oocyte RS > } \\
\text { Nearly mature mouse oocyte RS }\end{array}$ & \\
\hline
\end{tabular}


Table 1. Cont.

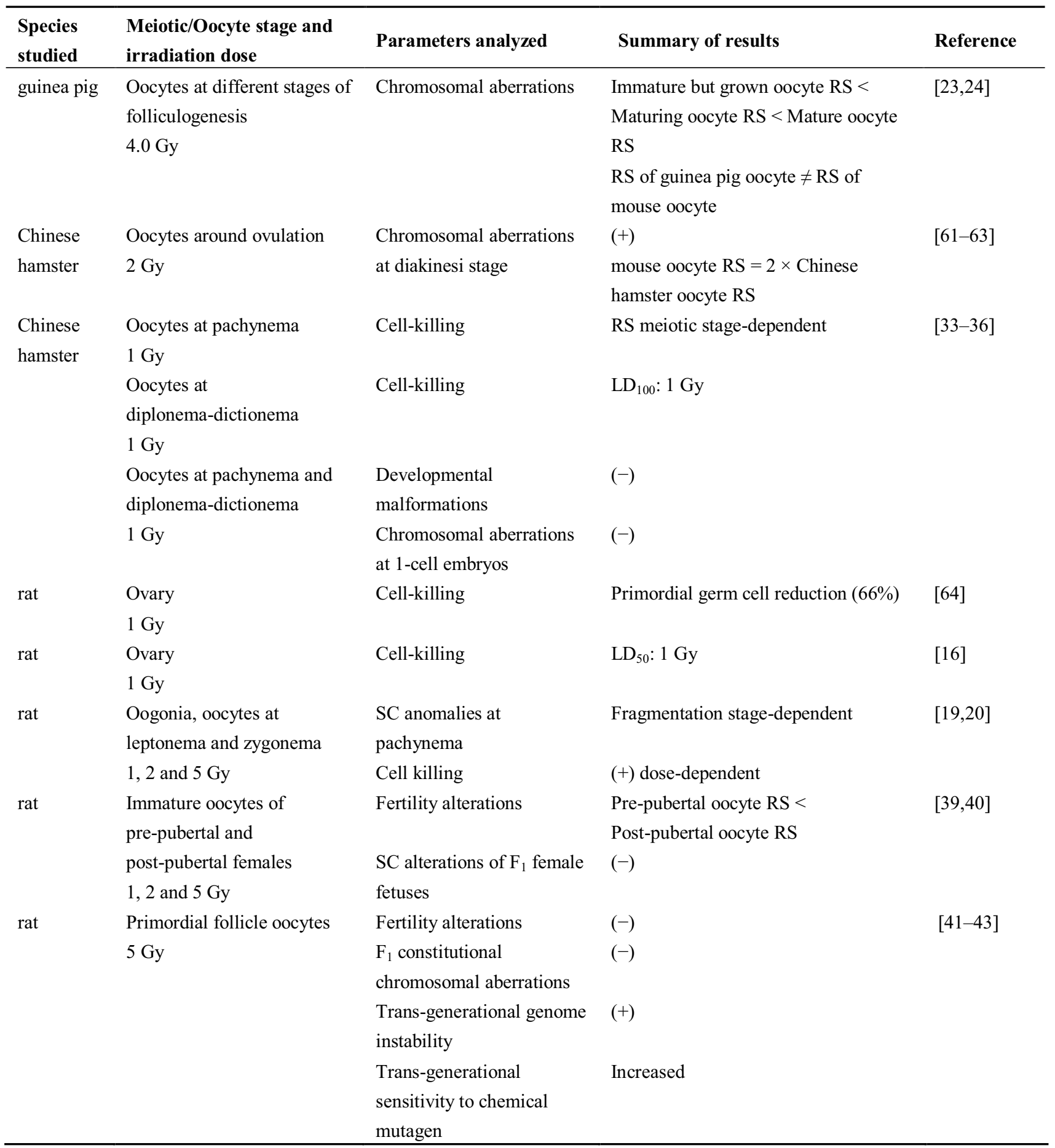

RS: radiation sensitivity; LD: lethal dose; SC: synaptonemal complex; Gy: Grey; $\mathrm{F}_{1}$ : progeny of the irradiated female, MI: metaphase I, MII: metaphase II; (+): the parameter analyzed is affected by ionizing radiation; $(-)$ : the parameter analyzed is not affected by ionizing radiation.

\section{Indicators of Radiation-Induced Genotoxic Effects}

As stated earlier, radiation-sensitivity is a complex affair given that it depends on several factors, such as type of irradiation, total dose irradiated, time-interval over which dose is received, type of cell affected or the stage of cell division irradiated, among others. At the same time, and as far as we know, the mechanism by which radiation causes damage to cells is by ionization of atoms in the molecules, 
which can affect the genetic material (DNA) or associated proteins. Therefore, the direct or indirect indicators of this primary damage are variable, and in this sense the results can be uncertain and even contradictory. Overall, when IR affects the DNA, two different categories can be established; short term effects (such as effect on DNA: DSBs, SSBs, among others) and long terms effects (cell killing and aneuploidies, among others). Here, we will provide a general view of the parameters that have been used in the literature for the assessment of radiation-induced biological effects, reflecting the high complexity of the state of the art.

\subsection{Cell Killing (Lethal Dose, LD)}

In toxicology, the lethal dose (also referred to as $\mathrm{LD}_{50}$, lethal dose $50 \%$ or median lethal dose) is an indicator used as a measure of cell killing and fertility. The $\mathrm{LD}_{50}$ for a particular substance (i.e., ionizing radiation) refers to the amount (mgr) necessary per weight $(\mathrm{kg})$ to cause death in $50 \%$ of the population under study. Early studies used this measure of toxicological effects of ionizing irradiation in mouse [16,58], rat [16,19,20,64], Chinese hamster [33-35] and guinea pig [27-30]. Results have been heterogeneous depending on the species studied and the moment of the irradiation (oocytes and pachynema, diplonema-dictionema or at the moment of birth). Although studies are scarce, the observed trend is that LD is species-dependent.

\subsection{Fertility Alterations}

Fertility alterations such as oocytes depletion, ovarian failure and loss of reproductive potential have also been used as indicators of radiation-induced genotoxic effects only in a few numbers of reports (Table 1). This includes studies in mouse [16,22], guinea pig [27-30] and rat [39-41]. The results so far are contradictory but the general observed trend is that fertility alterations do not seem to be related to the species irradiated but rather to the irradiation timing.

\subsection{Developmental Malformations}

Developmental malformations are anatomical or structural abnormalities observed at birth and may be caused by genetic factors or environmental alterations (or a combination of the two) that occur during prenatal development. Although genetic factors are the most common causes of developmental malformations, the underlying mechanisms are complex and not well known. Due to this complexity, only few authors have used developmental malformations as indicators of radio-induced insults (Table 1). At the same time, the results obtained so far (either positive or negative) can even be contradictory due to the great diversity of alterations that can be considered as "malformations", as well as to different moments (pre- and post-implantation, for example) when observed.

\subsection{Genetic Mutations}

The DNA double-strand breaks (DSBs) produced by IR constitute a particular hazard to cells and can result in genetic mutations that can be evaluated. Several parameters are used to evaluate radiation-induced genetic mutations, and here we will review those that can directly affect the DNA 
(i.e., dominant lethal effects, locus-specific mutations, chromosomal aberrations, genomic instability) or associated proteins (i.e., synaptonemal complex).

A parameter that has been traditionally used in toxicology has been the dominant lethal effects, (DL) $[44,45,57]$. DL events are genetic effects cause by any physical or chemical agent that causes embryonic or fetal death, indicating that the substance has affected germinal tissue. According to the OECD (Organization for Economic Co-operation and Development) guidelines for the testing of chemicals, "a dominant lethal mutation is one occurring in a germ cell which does not cause dysfunction of the gamete but which is lethal to the fertilized egg or developing embryo". Therefore, DL causes embryonic or fetal death. They are generally accepted to be the result of chromosomal damage, but gene mutations and toxic effects cannot be excluded. Studies performed in golden hamster, mouse and guinea pig $[44,45,57]$ have revealed that the radiation sensitivity obtained from evaluating DL is both species- and oocytes stage-dependent (Table 1).

Additionally, locus-specific mutations have been used to detect recessive mutations induced in diploid organisms: a strain that carries several known recessive mutations in a homozygous condition is crossed with a non-mutant treated strain in order to look for these recessive mutations in the progeny. This has been the case of mutations in genes controlling mouse fur color, a method initially developed by Russell and Russell [65] and applied later on. However, this method has been reported to have low mutation rates and therefore low sensitivity to detect trans-generational effects [66]. An alternative to overcome this limitation is the detection of loci containing repetitive sequence elements (expanded simple tandem repeat_ESTR_DNA loci), which are known to mutate at an extremely high frequency [67]. Jointly with chromosomal reorganizations, this has been the technique most widely used to detect trans-generational genotoxic effects of chemical and physical (i.e., IR) agents, as we shall see later on.

When IR damages DNA and induces chromosomal anomalies through the formation of DSBs, such alterations can be stabilized through chromosomal rearrangements or capped by the addition of telomeric sequences, producing chromosomal aberrations. Revisions focused on different types of radiation-induced chromosomal reorganizations previously have been reported elsewhere [68], so here a brief summary is provided. As a general overview, chromosomal reorganizations induced by IR are mainly structural changes resulting in inversions (either paracentric or pericentric), translocations, fusions and fissions, among others, and to a lesser extent, numerical. These structural aberrations can be considered as (i) chromatid-type or (ii) chromosome-type. The former affects one of the sister-chromatids, whereas both sister-chromatids are involved in the latter. Both types of chromosomal aberrations have been used as reliable biomarkers for genetic radio-induced damage. When occurring in the germ line, chromosomal aberrations can lead to aneuploidy and/or constitutional aberrations in the offspring.

In a genome-wide broader scale, the increased rate of alterations produced by the effect of IR is known as radiation-induced genomic instability (RIGI) [69]. Genomic instability is a term initially used to describe a phenomenon that results in the accumulation of multiple changes required to convert a stable genome of a normal cell into an unstable genome characteristic of a tumor, and it is known that this can be caused by radiation [70]. RIGI can be measured by the formation of gene amplification, micronucleus formation and microsatellite instability, as well as chromosomal reorganizations, and its effects are dependent on the genetic background of the cell [71]. When 
inducing genetic abnormalities that can be propagated in the offspring, "trans-generational RIGI" can also be measurable as a biomarker for radio-induced genotoxic effects [41].

Radiation-induced genetic mutations can also be measured by analyzing the proteins associated with the DNA. In the case of the germ line, the synaptonemal complex (SC) has been used as a biomarker for genotoxic effects $[20,21,40]$. SC is a meiosis-specific protein structure that promotes synapsis (pairing of homologous chromosomes) and recombination events during the first meiotic prophase [72-74]. SC consists of two parallel lateral elements (LE), one central element (CE), and numerous transverse filaments (TF) (reviewed in [74]). The Synaptonemal Complex Proteins 2 and 3 (SYCP2 and SYCP3) are layered onto cohesin proteins producing the lateral elements of SC during the first meiotic prophase, whereas the transverse filament protein SCP1 [75] bridges the lateral elements at pachynema. Recent results have shown that the synaptonemal complex is required for both synapsis and the structural integrity of the chromosome axis [76]. Moreover, the repair of meiotic DSBs is impaired in the absence of SC in mice, highlighting the importance of this structure for the correct progression of meiosis in mammals [76]. Cytogenetic studies have used the synaptonemal complex as a biomarker for the genotoxic effects induced by IR, given that any chromosomal aberration can be detected when the SC is completely assembled during the pachytene stage $[20,21,40,77]$. Early studies performed by Allen and collaborators [78] detected three main types of SC abnormalities induced by chemical mutagens in male mice: (i) synaptonemal complex fragmentation, (ii) synaptic abnormalities and (iii) mispairing, or heterosynapsis. Later studies have identified other types of abnormalities, in most cases stage-dependent, of which the most common ones are chromosomal reorganizations that can be observed as circles, single or double, multivalents and loops [20,77,78]. Moreover, alterations in synapsis can also be also detectable, such as partial and/or complete asynapsis (reflected by the presence of univalents or bivalents with unpaired regions) or non-homologous pairing [19]. Very few studies have been focused on the radio-induced genotoxic effects in early stage of meiosis (oogonia and prophase I oocytes) and they are restricted to rat [19,20,39,40], mouse [21], Chinese hamster [33] and guinea pig [27]. Out of these, the studies performed in rat and mouse [19-21,39,40] have used SC as an indicator for genotoxic effects.

\section{Radiation-Induced Genotoxic Effects in Mammalian Female Germ-Cells}

The literature is rather scarce in experiments in vivo in which female mammalian species were treated with IR and genetic alterations were analyzed in their germ cells or their progeny (Table 1). In general terms, irradiation studies performed on female mammalian germinal cells have demonstrated that radiation sensitivity is dependent on several factors, such as radiation dose (although the dose-effect relationship is poorly known), meiotic oocyte stage (taking into account the granulosa cells of the follicle), the parameter or measurable endpoint used and the species analyzed. Due to the intrinsic difficulties for the study of human meiosis, four main experimental model species have been used for radiation-sensitivity analysis (mouse, rat, guinea pig and Chinese hamster), resulting in a heterogeneous picture that makes it difficult to provide definitive conclusions by extrapolating results among species. As an example, when the parameters analyzed are chromosomal aberrations, DL and/or congenital malformations, studies have reported that oocyte radiation-sensitivity increased two-fold in the Chinese hamster, when compared to the mouse [34,35,61]. However, in the case of 
chromosome aberrations detected at MI/MII, the mature oocytes from guinea pig are more radio-sensitive than are mature mouse oocytes [23,79]. Despite this apparent disparity in results, depending on the species analyzed, it seems that a general trend can be outlined. In this section we will review the radiation-induced genotoxic effects studied in animal models by considering two different levels of analysis: (i) deleterious effects detected in maternal oocytes $\left(\mathrm{F}_{0}\right)$ and (ii) the genotoxic effects detected in $\mathrm{F}_{1}$, through the analysis of trans-generational genome instability (chromosomal alterations and genetic mutations), aneuploidy, fertility and/or developmental malformations.

\subsection{Analyzing the $F_{0}$}

Most of our knowledge regarding the radiation sensitivity of the female germ cells comes mainly from experiments performed in mice and, to a lesser extent, in rat, guinea pig and Chinese hamster. Radiation-induced genotoxic effects have been studied throughout all meiotic stages: oogonia, oocyte I (at leptonema, zygonema, pachynema or diplonema), immature oocytes (oocytes I at primordial or unilaminar follicles), maturing oocytes (oocytes I at pre- and antral follicles) and mature oocytes (oocytes I/oocytes II at pre- and ovulatory follicles) (Figure 1, Table 1). Moreover, there are also studies focused on post-conception stages, mainly at the zygote and pre-implantation stages (1-cell to blastocyst) and post-implantation stages (Table 1). All of these studies indicate that oocyte radiation-sensitivity depends on its developmental stage and its relation with folliculogenesis.

As already stated, few studies have focused on oogonia and prophase I oocytes [19-21,39,40]. Pujol and collaborators [19,20] analyzed the effect of different doses of X-rays (1 Gy, 2 Gy and 5 Gy) on the number of recoverable germ cells in female rat fetuses irradiated at three different days of gestation (d.g.): 14 d.g. (oogonia), 16 d.g. (leptonema) and 18 d.g. (zygonema). At 14 d.g., all germ cells are at the stage of mitotic proliferation, and as a result many oogonia are expected to be at the $\mathrm{S}$ phase of mitosis. At $16 \mathrm{~d}$.g., many cells are completing their last mitotic division, and others have already entered the first meiotic prophase, whereas at $18 \mathrm{~d}$.g. most cells have reached leptonema or lepto-zygonema. Their results indicate that irradiation significantly decreases the number of germ cells, and increases the incidence of synaptonemal complex fragmentation, suggesting that differences in sensitivity to irradiation depend on the meiotic stage at the time of irradiation. Differences in radiation doses were also observed; the 5 Gy dose is lethal for oogonia and zygotene oocytes, while for leptotene oocytes, this dose could have a sub lethal effect. Overall, Pujol and collaborators [19,20] show that SC fragmentation is stage-dependent; they found a significant increase in the incidence of heterosynapses in oogonia, a significant increase in the frequency of structural anomalies in leptotene oocytes and a significant increase in nuclear fragmentation in zygotene oocytes. Similar results were obtained by Johannisson and co-workers [21], when fetal female mice were exposed to ionizing irradiation of $2 \mathrm{~Gy}$ in a single dose at 14, 16, and $17 \mathrm{~d} . \mathrm{g}$., indicating that at early stages of meiosis, the genotoxic effects of IR are not species-dependent.

Studies on immature and mature oocytes are more abundant in the literature. Overall, the observed general view is that mature oocytes are more radio-sensitive than are immature oocytes. These observations were already reported by early studies in mouse [16,37,46,54,55,65,80]. Later on, this trend was confirmed in other model species such as rat and guinea pig. Studies conducted in rat $[39,40]$ showed that pre-pubertal dictiotene oocytes are less radio-sensitive than are post-pubertal dictiotene 
oocytes. In the same vein, and according to studies performed by Jacquet's lab in guinea pig [23,30,79], immature oocyte are less radiation-sensitive than are maturing oocytes, and these are less radiation-sensitivity than are mature oocytes. On the other hand, it has been reported that the chromosomal sensitivity of immature dictiotene oocytes enclosed in primordial follicles is very low in the guinea pig [45]. In the late pre-antral stages the sensitivity of the oocyte gradually increases to reach a maximum at the antral stage of folliculogenesis. The same occurs in the Chinese hamster, where oocytes surrounding ovulation show the greatest sensitivity to radiation [62].

During oocyte maturation (between one day and six weeks after irradiation in the mouse), regardless of the fact that in all cases oocytes are arrested at the dictiotene prophase I stage, differences in radiation sensitivity have been reported. In mouse, ovulated oocytes (MII stage) analyzed one day to two weeks post-irradiation are less sensitive to the induction of chromosomal aberrations, genetic mutations and dominant lethal effects (DL) than are ovulated oocytes analyzed after three weeks and six weeks post-irradiation [47,57,80]. In particular, Tease [47] observed that at medium/high doses (100 cGy-600 cGy) radio-induced chromosomal aberrations increased two-fold in immature oocytes in relation to mature oocytes (Table 1). Ovulation is another key point. A few hours before ovulation, pre-ovulatory oocytes are more radio-sensitive, given that some studies have reported a significant increase in chromosomal aberrations $[37,48,49,56]$ and chromosomal non-disjunction [81] in mouse irradiated at low doses $(0.1 \mathrm{~Gy}-0.5 \mathrm{~Gy})$. Analyzing DL, other authors have found that pre-ovulatory oocytes are radiosensitive in mouse $[65,82]$ and rat [83]. Therefore, the sensitivity to the induction of genetic damage is dependent on the stage of folliculogenesis and, in this sense, the interval between irradiation and ovulation.

At this point and taking into account published data on mammalian females (human included), we can consider that the genetic radiation-sensitivity observed in the human female is related to the size of the follicles in the way that small follicles are apparently less sensitive to cell-killing than are large follicles. In the case of mouse germ cells, radiation-sensitivity is related to the folliculogenesis stage (Figure 2) with its maximum sensitivity in early diakinesi (as seems to happen in Chinese hamster) and its minimum in the full antral stage. The few data published on the human female $[11,12,16]$ differ from those obtained in guinea pig, where the maximum sensitivity would be in the full antral stage (Figure 2). Pre- and antral follicles have a larger (both in number and volume) granulose layer than do primordial follicles, probably acting as a protective screen against the genotoxic effects of radiation. Therefore, why, in some species, are mature oocytes more radio-sensitive than are immature oocytes? One has to take into account that a follicle works as a functional syncytium, so the response may lie in how the DNA damage-response changes during oocyte development and how they are challenged by ionizing irradiation. Moreover, we have to bear in mind, however, that all parameters used in the literature to measure radiation-induced genotoxic effects are highly diverse (from chromosomal alterations to cell-killing and congenital malformations) and, therefore, the repair mechanisms involved might be different so, therefore, we have to be extremely cautious when extrapolating the data. Notwithstanding these differences, a wide variety of direct and indirect evidence indicates that oocytes maintain their capacity to repair DNA insults during their maturation process [84-90]. In a recent study, Wang and collaborators [91] described the proteome of mouse oocytes at different developmental stages, the dictiotene or germinal vesicle $(\mathrm{GV})$ stage, the metaphase II (MII) stage and zygote stage (fertilized oocyte). Surprisingly, the authors found that more DNA repair proteins are 
expressed in MII oocytes than in GV oocytes or the zygote; they included in the analysis the proteins involved in the SSB repair and nucleotide-excision repair pathways. Moreover, they found that the DNA recombination pathway and DNA replication protein families are also more abundant in MII oocytes. In particular, 35 out of 53 proteins involved in the DNA repair process identified in both MII oocytes and zygotes are up-regulated in the MII oocytes. These include Rad51, BRCA2, XRCC1, PARP1 and TRIP13. These results are consistent with previous findings on gene expression profiles of oocytes and early embryos [92], which suggest that the over-representation of genes involved in DNA repair confer protection to maintain genome stability of the female germ-line.

Figure 2. Comparison between genetic radiation-sensitivity observed in mouse and Guinea pig females.

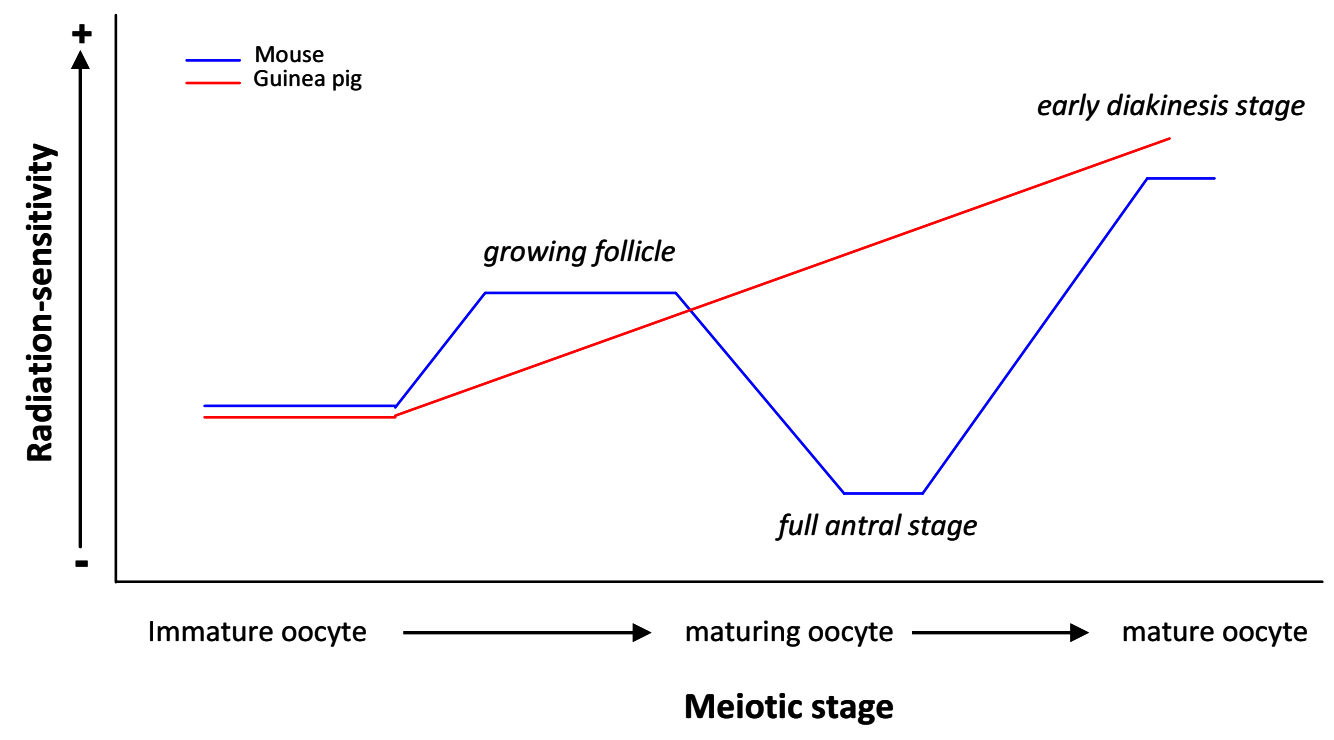

Based on the evidence, a possible interpretation of differences in radiation-sensitivity during oocyte maturation is that mature oocytes repair genetic insults by means of "prone to error" mechanisms, stabilizing alterations through chromosomal rearrangements. That would explain why chromosomal aberrations are frequently observed at MII $[37,49,50,93]$. On the contrary, immature oocytes would not efficiently repair the genetic insults, resulting in cell death and not contributing to the offspring. Species differences to the genotoxic effects of IR can also be attributed to differences in the implementation of DDR and, therefore, more studies are needed to overcome any disparity in reports.

\subsection{Trans-Generational Studies}

When an increased rate of mutation or augmentation of developmental malformations, to name two different measurable endpoints, is observed in the non-exposed offspring of irradiated parents, we are facing trans-generational genomic instability [37,49,50,93]. According to Barber and Dubrova [94], the first evidence of a trans-generational effect for ionizing radiation was demonstrated by Luning et al. [95], who observed elevated rates of dominant lethal mutations in the non-exposed first-generation $\left(F_{1}\right)$ offspring of males injected with $239^{\mathrm{Pu}}$ citrate solution. Data on potential trans-generational genomic instability following irradiation are largely limited to males [94,96-99], and only until very recently did studies in females begin to flourish [39-43,51,60]. Early studies 
evaluated the genotoxic effects in prophase I stages (pachynema, diplonema and dictionema oocytes) in the Chinese hamster [33-35]. After exposing animals to a single dose of $1 \mathrm{~Gy}$, the authors did not observe a significant increase of chromosomal aberrations in one-cell embryos and/or developmental alterations among the progeny of the irradiated females. Therefore, and although these studies detected that radio-resistance was stage-dependent, they did not observe any trans-generational effects with these measurable endpoints. Subsequent studies in mice by Pils and collaborators [22] studied the genotoxic effects when irradiating females at the zygote stage. They not only obtained positive results when looking for fertility alterations of these irradiated females, but they also found an increment of congenital malformations in the $F_{1}$ progeny. Nevertheless, years later, Jaquet and co-workers [24] reported negative findings regarding developmental defects and genomic instability (analyzing chromosomal aberrations) in the $F_{1}$ and after exposure of low doses of irradiation at the mouse female zygote stage ( 0.2 and 0.4 Gy instead of 1 Gy used by Pils et al. [22]). Here, the authors suggested differences in the mouse strain and sex-radiation sensitivities. Interestingly, studies leaded by Dubrova's group [51,60], based on the analysis of expanded simple-tandem repeats (ESTR), indicate that whereas paternal irradiation destabilizes the genomes of non-exposed offspring, maternal irradiation does not affect stability of their offspring. Taking together, these data show that the trans-generational effects in the offspring of irradiated male mice may be explained by a genome-wide destabilization, which manifests in many, possibly all, tissues. Why this behavior regarding ESTR is not observed in females needs further validation.

Others have studied trans-generational genomic instability through the analysis of chromosomal alterations detected in fibroblasts derived from fetuses, which resulted from fertilization of irradiated oocytes [25,26,39-43]. In their initial studies using mouse as a model species, Pampfer and Streffer [25] assumed that the observed structural chromosomal aberrations were not induced directly by radiation exposure and the radiation exposure of the zygote has led to instability of the genome so that "spontaneous" aberrations occurred more frequently. In doing so, these authors had already detected an increase in trans-generational chromosomal aberrations in mouse zygotes and, although these former results were not totally conclusive, "the intuited" trans-generational chromosomal instability in mouse was corroborated by Streffer, [26] some years later. To our knowledge, there is only one published work in mouse with trans-generational positive results [49]. In this case the statically significant $F_{1}$ chromosomal aberrations only correspond to pre-implantation stages as if the chromosomal aberrations were life-incompatible with later stages.

\subsection{The Rat as a Model Species}

Mirroring the commented effects in mouse, studies in rat performed by our group came to similar conclusions. The rat has been used as a model species for evaluating the radiation-induced genotoxic effects in mammalian female germ cells, either in the irradiated females or in the offspring [19,20,39-43]. In general terms, studies of trans-generational radiation-induced genotoxic effects on the gonadal function of rat females, using mainly SCs or chromosomal alterations as measurable endpoint markers, have concluded that, in the case of $\mathrm{F}_{0}$ fetal oocytes, cell-killing is dose-dependent and that SC fragmentation is prophase-stage-dependent $[19,20]$. Moreover, no trans-generational cytogenetic effects were observed in the progeny of irradiated females, indicating that those oocytes 
that remain after irradiation do not present genome instability or any constitutional aberration in the SCs. The same occurs when studying the $F_{1}$ fetal oocytes from pre-pubertal and adult irradiated mothers by SCs where the remaining oocytes do not present either genome instability or any constitutional aberration, although there is an induction of apoptosis in the fetal rat germ cells $[39,40]$. More recently, we studied fibroblasts derived from fetuses of irradiated mothers [41-43], and in this case, a radiation-induced chromosomal instability was observed (an increase of chromosomal instability but not constitutional chromosomal alterations) in the offspring of irradiated females. In our view, this apparent contradiction to previous data [39,40] suggests that the use of chromosomal parameters and not just the analysis of SCs is more efficient in detecting germ cell genomic instability.

\section{Human Females: An Approachable Model? Future and Prospects}

Most of the current knowledge of the genotoxic effect of IR in the human female germ cell line came from epidemiological studies among atomic disaster survivors (i.e., Chernobyl), radiation workers or cancer patients that have been submitted to radiotherapy (reviewed in [53]). But we have seen that data on mammalian females are controversial so far due to the disparity in type of irradiation, doses employed, parameters analyzed (chromosomal reorganizations, congenital effects, frequency of microsatellite mutations, among others), age and exposure to environmental factors. Moreover, and due to the intrinsic characteristics of human female gametogenesis (i.e., progression during fetal development), its study has been limited to sampling availability. Only until very recently have new efforts been directed to the development of an in vitro system that allows meiotic progression in a sytematically and reproducible way; this technique in the future will allow us to molecularly study the evolution of the human female meiotic prophase in a systematic way, thus avoiding the side-effects of in vivo studies. Our group and others have worked on establishing the conditions that will allow female meiotic progression in vitro [100-108]. Some of them have indeed used organotypic culture models to investigate the radio-sensitivity of early female proliferating germ cells [107]. However, the method developed recently by Brieño-Enríquez and co-workers signifies a breakthrough in the study of meiosis, since it is the first culture system that allows mammalian meiocytes to continue meiosis in vitro ever reproduced. This method represents a new way to test the toxicity of chemical $[106,109]$ as well as physical [110] agents to be used in humans, opening new avenues for the study of oogenesis development and regulation in female reproduction.

\section{Conclusions}

In summary, irradiation studies performed on germinal cells from mammalian females have demonstrated that radiation sensitivity is a complex affair. Oocyte radiation sensitivity is always dose-dependent, although there is no doses-effect relationship described. Usually, radiation sensitivity is dependent on the meiotic/oocyte-irradiated stage and, in some cases, species-dependent. Overall, we can consider that the genotoxic effects are dependent on the parameters analyzed and could be considered to be stage-dependent. 


\section{Acknowledgments}

This work was funded by a grant from CIDEM (Catalan Government), VALTEC09-1-0007. This manuscript was proofread by a native English-speaking Instructor of English of the Universitat Autònoma de Barcelona.

\section{References and Notes}

1. Lord, C.J.; Ashworth, A. The DNA damage response and cancer therapy. Nature 2012, 481, 287-294.

2. Valerie, K.; Povirk, L.F. Regulation and mechanisms of mammalian double-strand break repair. Oncogene 2003, 22, 5792-5812.

3. Jaco, I.; Muñoz, P.; Goytisolo, F.; Wesoly, J.; Bailey, S.; Taccioli, G.; Blasco, M.A. Role of mammalian Rad54 in telomere length maintenance. Mol. Cell Biol. 2003, 23, 5572-5580.

4. Salzano, A.; Kochiashvili, N.; Nergadze, S.G.; Khoriauli, L.; Smirnova, A.; Ruiz-Herrera, A.; Mondello, C.; Giulotto, E. Enhanced gene amplification in human cells knocked down for DNA-Kcs. DNA Repair 2009, 8, 19-28.

5. Ruiz-Herrera, A.; Smirnova, A.; Khouriauli, L.; Nergadze, S.G.; Mondello, C.; Giulotto, E. Gene amplification in human cells knocked down for RAD54. Genome Integr. 2011, 2, doi:10.1186/2041-9414-2-5.

6. Keeney, S.; Giroux, C.N.; Kleckner, N. Meiosis-specific DNA double-strand breaks are catalyzed by Spo11, a member of a widely conserved protein family. Cell 1997, 88, 375-384.

7. Roeder, G.S. Meiotic chromosomes: It takes two to tango. Genes Dev. 1997, 11, 2600-2621.

8. Moens, P.B.; Kolas, N.K.; Tarsounas, M.; Marcon, E.; Cohen, P.E.; Spyropoulos, B. The time course and chromosomal localization of recombination-related proteins at meiosis in the mouse are compatible with models that can resolve the early DNA-DNA interactions without reciprocal recombination. J. Cell Sci. 2002, 115, 1611-1622.

9. Baker, S.M.; Plug, A.W.; Prolla, T.A.; Bronner, C.E.; Harris, A.C.; Yao, X.; Christie, D.M.; Monell, C.; Arnheim, N.; Bradley, A.; et al. Involvement of mouse Mlh1 in DNA mismatch repair and meiotic crossing over. Nat. Genet. 1996, 13, 336-342.

10. Turner, J.M.; Aprelikova, O.; Xu, X.; Wang, R.; Kim, S.; Chandramouli, G.V.; Barrett, J.C.; Burgoyne, P.S.; Deng, C.X. BRCA1, histone H2AX phosphorylation, and male meiotic sex chromosome inactivation. Curr. Biol. 2004, 14, 2135-2142.

11. Wallace, W.H.; Thomson, A.B.; Kelsey, T.W. The radiosensitivity of the human oocyte. Hum. Reprod. 2003, 18, 117-121.

12. Wallace, W.H.; Thomson, A.B.; Saran, F.; Kelsey, T.W. Predicting age of ovarian failure after radiation to a field that includes the ovaries. Int. J. Radiat. Oncol. Biol. Phys. 2005, 62, 738-744.

13. Diehn, M.; Cho, R.W.; Clarke, M.F. Therapeutic implications of the cancer stem cell hypothesis. Semin. Radiat. Oncol. 2009, 19, 78-86.

14. Russell, L.B.; Russell, W.L. Frequency and nature of specific-locus mutations induced in female mice by radiations and chemicals: A review. Mutat. Res. 1992, 296, 107-127. 
15. Adler, I.D.; Carere, A.; Eichenlaub-Ritter, U.; Pacchierotti, F. Gender differences in the induction of chromosomal aberrations and gene mutations in rodent germ cells. Environ. Res. 2007, 104, 37-45.

16. Baker, T.G. Comparative aspects of the effects of radiation during oogenesis. Mutat. Res. 1971, 11, 9-22.

17. Pepling, M.E.; Spradling, A.C. Mouse ovarian germ cell cysts undergo programmed breakdown to form primordial follicles. Dev. Biol. 2001, 234, 339-351.

18. Kerr, J.B.; Duckett, R.; Myers, M.; Britt, K.L.; Mladenovska, T.; Findlay, J.K. Quantification of healthy follicles in the neonatal and adult mouse ovary: Evidence for maintenance of primordial follicle supply. Reproduction 2006, 132, 95-109.

19. Pujol, R.; Cusido, L.; Rubio, A.; Egozcue, J.; Garcia, M. Effect of X-rays on germ cells in female fetuses of Rattus norvegicus irradiated at three different times of gestation. Mutat. Res. 1996, $356,247-253$.

20. Pujol, R.; Cusido, L.; Rubio, A.; Egozcue, J.; Garcia, M. X-ray-induced synaptonemal complex damage during meiotic prophase in female fetuses of Rattus norvegicus. Mutat. Res. 1997, 379, 127-134.

21. Johannisson, R.; Mormel, R.; Brandenburg, B. Synaptonemal complex damage in fetal mouse oocytes induced by ionizing irradiation. Mutat. Res. 1994, 311, 319-328.

22. Pils, S.; Muller, W.U.; Streffer, C. Lethal and teratogenic effects in two successive generations of the hlg mouse strain after radiation exposure of zygotes-Association with genomic instability? Mutat. Res. 1999, 429, 85-92.

23. Jacquet, P.; Buset, J.; Vankerkom, J.; Baatout, S.; de Saint-Georges, L.; Baugnet-Mahieu, L.; Desaintes, C. Radiation-Induced chromosome aberrations in guinea-pig growing oocytes, and their relation to follicular atresia. Mutat. Res. 2001, 473, 249-254.

24. Jacquet, P.; Buset, J.; Neefs, M.; Vankerkom, J.; Benotmane, M.A.; Derradji, H.; Hildebrandt, G.; Baatout, S. Transgenerational developmental effects and genomic instability after x-irradiation of preimplantation embryos: Studies on two mouse strains. Mutat. Res. 2010, 687, 54-62.

25. Pampfer, S.; Streffer, C. Increased chromosome aberration levels in cells from mouse fetuses after zygote x-irradiation. Int. J. Radiat. Biol. 1989, 55, 85-92.

26. Streffer, C. Transgenerational transmission of radiation damage: Genomic instability and congenital malformation. J. Radiat. Res. 2006, 47, B19-B24.

27. Jacquet, P.; Vankerkom, J.; Lambiet-Collier, M. The female guinea pig, a useful model for the genetic hazard of radiation in man; preliminary results on germ cell radiosensitivity in foetal, neonatal and adult animals. Int. J. Radiat. Biol. 1994, 65, 357-367.

28. Jacquet, P.; de Saint-Georges, L.; Vankerkom, J.; Baugnet-Mahieu, L. Embryonic death, dwarfism and fetal malformations after irradiation of embryos at the zygote stage: Studies on two mouse strains. Mutat. Res. 1995, 332, 73-87.

29. Jacquet, P.; de Saint-Georges, L.; Buset, J.; Baatout, S.; van kerkom, J.; Baugnet-Mahieu, L. Cytogenetic effects of x-rays in the guinea pig female germ cells. I. The immature oocyte. Mutat. Res. 1997, 391, 189-192. 
30. Jacquet, P.; de Saint-Georges, L.; Buset, J.; Baatout, S.; Vankerkom, J.; Baugnet-Mahieu, L. Cytogenetic effects of $x$-rays in the guinea pig female germ cells. II. The maturing oocyte. Mutat. Res. 1997, 391, 193-199.

31. Muller, W.U.; Schotten, H. Induction of malformations by x-ray exposure of various stages of the oogenesis of mice. Mutat. Res. 1995, 331, 119-125.

32. Gu, Y.; Kai, M.; Kusama, T. The embryonic and fetal effects in ICR mice irradiated in the various stages of the preimplantation period. Radiat. Res. 1997, 147, 735-740.

33. Tateno, H.; Mikamo, K. Neonatal oocyte development and selective oocyte-killing by X-rays in the chinese hamster, Cricetulus griseus. Int. J. Radiat. Biol. Relat. Stud. Phys. Chem. Med. 1984, 45, 139-149.

34. Tateno, H.; Mikamo, K. Effects of neonatal ovarian x-irradiation in the chinese hamster. I. Correlation between the age of irradiation and the fertility span. J. Radiat. Res. 1989, 30, 185-190.

35. Tateno, H.; Mikamo, K. Effects of neonatal ovarian x-irradiation in the chinese hamster. II. Absence of chromosomal and developmental damages in surviving oocytes irradiated at the pachytene and resting dictyate stages. J. Radiat. Res. 1989, 30, 209-217.

36. Tateno, H.; Mikamo, K. Absence of late effects on survival and developmental abilities of pachytene oocytes x-irradiated during neonatal stages in the chinese hamster. Int. J. Radiat. Biol. Relat. Stud. Phys. Chem. Med. 1986, 49, 121-130.

37. Reichert, W.; Hansmann, I.; Rohrborn, G. Chromosome anomalies in mouse oocytes after irradiation. Humangenetik 1975, 28, 25-38.

38. Reichert, W.; Buselmaier, W.; Vogel, F. Elimination of X-ray-induced chromosomal aberrations in the progeny of female mice. Mutat. Res. 1984, 139, 87-94.

39. Martinez-Flores, I.; Egozcue, J.; Garcia, M. Effects on female fertility and germinal cells in prepubertal and adult rats (Rattus norvegicus) after X-ray irradiation. Adv. Exp. Med. Biol. 1998, 444, 215-219.

40. Martinez-Flores, I.; Saez, C.; Egozcue, J.; Garcia, M. Effects of ionizing radiation on oocytes of prepubertally irradiated rats. Int. J. Radiat. Biol. 2000, 76, 1403-1407.

41. Camats, N.; Garcia, F.; Parrilla, J.J.; Calaf, J.; Martin-Mateo, M.; Caldes, M.G. The GnRH analogue triptorelin confers ovarian radio-protection to adult female rats. Mutat. Res. 2009, 669, 67-79.

42. Camats, N.; Ruiz-Herrera, A.; Parrilla, J.J.; Acien, M.; Paya, P.; Giulotto, E.; Egozcue, J.; Garcia, F.; Garcia, M. Genomic instability in rat: Breakpoints induced by ionising radiation and interstitial telomeric-like sequences. Mutat. Res. 2006, 595, 156-166.

43. Camats, N.; Garcia, F.; Parrilla, J.J.; Calaf, J.; Martin, M.; Caldes, M.G. Trans-generational radiation-induced chromosomal instability in the female enhances the action of chemical mutagens. Mutat. Res. 2008, 640, 16-26.

44. Cox, B.D.; Lyon, M.F. X-ray induced dominant lethal mutations in mature and immature oocytes of guinea-pigs and golden hamsters. Mutat. Res. 1975, 28, 421-436.

45. Caine, A.; Lyon, M.F. The induction of chromosome aberrations in mouse dictyate oocytes by X-rays and chemical mutagens. Mutat. Res. 1977, 45, 325-331.

46. Brewen, J.G.; Payne, H.S.; Preston, R.J. X-ray-induced chromosome aberrations in mouse dictyate oocytes. I. Time and dose relationships. Mutat. Res. 1976, 35, 111-120. 
47. Tease, C. Dose-related chromosome non-disjunction in female mice after x-irradiation of dictyate oocytes. Mutat. Res. 1985, 151, 109-119.

48. Tease, C.; Fisher, G. X-ray-induced chromosome aberrations in immediately preovulatory oocytes. Mutat. Res. 1986, 173, 211-215.

49. Tease, C.; Fisher, G. Cytogenetic and genetic studies of radiation-induced chromosome damage in mouse oocytes. I. Numerical and structural chromosome anomalies in metaphase II oocytes, pre- and post-implantation embryos. Mutat. Res. 1996, 349, 145-153.

50. Griffin, C.S.; Tease, C.; Fisher, G. The effect of low-dose x-irradiation on numerical and structural chromosome anomaly induction in mouse immature oocytes. Mutat. Res. 1990, 231, 137-142.

51. Barber, R.C.; Hardwick, R.J.; Shanks, M.E.; Glen, C.D.; Mughal, S.K.; Voutounou, M.; Dubrova, Y.E. The effects of in utero irradiation on mutation induction and transgenerational instability in mice. Mutat. Res. 2009, 664, 6-12.

52. Garcia-Caldés, M.; Camats, N.; Pujol, R. Efectos Hereditarios de las Radiaciones Ionizantes en Hembras de mamíferos. In Genética Toxicológica, 1st ed.; Mudry, M.D., Carballo, M.A., Eds.; De los Cuatro Vientos: Buenos Aires, Argentina, 2006; pp. 359-392.

53. Adriaens, I.; Smitz, J.; Jacquet, P. The current knowledge on radiosensitivity of ovarian follicle development stages. Hum. Reprod. Update 2009, 15, 359-377.

54. Russell, W.L. Effect of the interval between irradiation and conception on mutation frequency in female mice. Proc. Natl. Acad. Sci. USA 1965, 54, 1552-1557.

55. Brewen, J.G.; Payne, H.S. X-ray-induced chromosome aberrations in mouse dictyate oocytes. II. Fractionation and dose rate effects. Genetics 1977, 87, 699-708.

56. Hansmann, I.; Jenderny, J.; Probeck, H.D. Nondisjunction and chromosome breakage in mouse oocytes after various X-ray doses. Hum. Genet. 1982, 61, 190-192.

57. Kirk, M.; Lyon, M.F. Induction of congenital anomalies in offspring of female mice exposed to varying doses of X-rays. Mutat. Res. 1982, 106, 73-83.

58. Dobson, R.L.; Felton, J.S. Female germ cell loss from radiation and chemical exposures. Am. J. Ind. Med. 1983, 4, 175-190.

59. Lomaeva, M.G.; Vasil'eva, G.V.; Fomenko, L.A.; Antipova, V.N.; Gaziev, A.I.; Bezlepkin, V.G. Increased genomic instability in somatic cells of the progeny of female mice exposed to acute $\mathrm{X}$-radiation in the preconceptional period. Genetika 2011, 47, 1371-1377.

60. Abouzeid Ali, H.E.; Barber, R.C.; Dubrova, Y.E. The effects of maternal irradiation during adulthood on mutation induction and transgenerational instability in mice. Mutat. Res. 2012, 732, 21-25.

61. Mikamo, K. Meiotic chromosomal radiosensitivity in primary oocytes of the chinese hamster. Cytogenet. Cell Genet. 1982, 33, 88-94.

62. Kamiguchi, Y.; Mikamo, K. Dose-response relationship for induction of structural chromosome aberrations in chinese hamster oocytes after x-irradiation. Mutat. Res. 1982, 103, 33-37.

63. Mikamo, K.; Kamiguchi, Y.; Funaki, K.; Sugawara, S.; Tateno, H. Stage-dependent changes of chromosomal radiosensitivity in primary oocytes of the chinese hamster. Cytogenet. Cell Genet. 1981, 30, 174-178. 
64. Beaumont, H.M. The effects of acute $\mathrm{x}$-irradiation on primordial germ-cells in the female rat. Int. J. Radiat. Biol. Relat. Stud. Phys. Chem. Med. 1966, 10, 17-28.

65. Russell, L.B.; Russell, W.L. The Sensitivity of Different Stages in Oogenesis to the Radiation Induction of Dominant Lethals and other Changes in the Mouse. In Progress in Radiobiology, 1st ed.; Mitchell, J.S., Holmes, B.E., Smith, C.C., Eds.; Oliver and Boyd Ltd.: Edinburgh, UK, 1956; pp. 187-192.

66. Dubrova, Y.E. Radiation-induced transgenerational instability. Oncogene 2003, 22, 7087-7093.

67. Dubrova, Y.E.; Plumb, M.A. Ionising radiation and mutation induction at mouse minisatellite loci. The story of the two generations. Mutat. Res. 2002, 499, 143-150.

68. Savage, J.R. A brief survey of aberration origin theories. Mutat. Res. 1998, 404, 139-147.

69. Morgan, W.F. Is there a common mechanism underlying genomic instability, bystander effects and other nontargeted effects of exposure to ionizing radiation? Oncogene 2003, 22, 7094-7099.

70. Smith, L.E.; Nagar, S.; Kim, G.J.; Morgan, W.F. Radiation-induced genomic instability: Radiation quality and dose response. Health Phys. 2003, 85, 23-29.

71. Kadhim, M.A. Role of genetic background in induced instability. Oncogene 2003, 22, 6994-6999.

72. Moses, M.J. Chromosomal structures in crayfish spermatocytes. J. Biophys. Biochem. Cytol. 1956, 2, 215-218.

73. Zickler, D.; Kleckner, N. Meiotic chromosomes: Integrating structure and function. Annu. Rev. Genet. 1999, 33, 603-754.

74. Yang, F.; Wang, P.J. The mammalian synaptonemal complex: A scaffold and beyond. Genome Dyn. 2009, 5, 69-80.

75. Dobson, M.J.; Pearlman, R.E.; Karaiskakis, A.; Spyropoulos, B.; Moens, P.B. Synaptonemal complex proteins: Occurrence, epitope mapping and chromosome disjunction. J. Cell. Sci. 1994, 107, 2749-2760.

76. Kouznetsova, A.; Benavente, R.; Pastink, A.; Hoog, C. Meiosis in mice without a synaptonemal complex. PLoS One 2011, 6, doi:10.1371/journal.pone.0028255.

77. Cusido, L.; Pujol, R.; Egozcue, J.; Garcia, M. Cyclophosphamide-induced synaptonemal complex damage during meiotic prophase of female Rattus norvegicus. Mutat. Res. 1995, 329, $131-141$.

78. Allen, J.W.; de Weese, G.K.; Gibson, J.B.; Poorman, P.A.; Moses, M.J. Synaptonemal complex damage as a measure of chemical mutagen effects on mammalian germ cells. Mutat. Res. 1987, 190, 19-24.

79. Jacquet, P.; Adriaens, I.; Buset, J.; Neefs, M.; Vankerkom, J. Cytogenetic studies in mouse oocytes irradiated in vitro at different stages of maturation, by use of an early preantral follicle culture system. Mutat. Res. 2005, 583, 168-177.

80. Brewen, J.G.; Payne, H.S. X-ray stage sensitivity of mouse oocytes and its bearing on dose-response curves. Genetics 1979, 91, 149-161.

81. Tease, C. Radiation-induced chromosome non-disjunction in oocytes stimulated by different doses of superovulating hormones. Mutat. Res. 1982, 105, 95-100.

82. Edwards, R.G.; Searle, A.G. Genetic radiosensitivity of specific post-dictyate stages in mouse oocytes. Genet. Res. 1963, 4, 389-398. 
83. Mandl, A.M. The radiosensitivity of oocytes at different stages of maduration. Proc. R. Soc. Lond. Ser. B 1963, 158, 119-141.

84. Ashwood-Smith, M.J.; Edwards, R.G. DNA repair by oocytes. Mol. Hum. Reprod. 1996, 2, 46-51.

85. Pan, H.; O’brien, M.J.; Wigglesworth, K.; Eppig, J.J.; Schultz, R.M. Transcript profiling during mouse oocyte development and the effect of gonadotropin priming and development in vitro. Dev. Biol. 2005, 286, 493-506.

86. Zheng, P.; Schramm, R.D.; Latham, K.E. Developmental regulation and in vitro culture effects on expression of DNA repair and cell cycle checkpoint control genes in rhesus monkey oocytes and embryos. Biol. Reprod. 2005, 72, 1359-1369.

87. Su, Y.Q.; Sugiura, K.; Woo, Y.; Wigglesworth, K.; Kamdar, S.; Affourtit, J.; Eppig, J.J. Selective degradation of transcripts during meiotic maturation of mouse oocytes. Dev. Biol. 2007, 302, 104-117.

88. Menezo, Y., Jr.; Russo, G.; Tosti, E.; El Mouatassim, S.; Benkhalifa, M. Expression profile of genes coding for DNA repair in human oocytes using pangenomic microarrays, with a special focus on ROS linked decays. J. Assist. Reprod. Genet. 2007, 24, 513-520.

89. Hamatani, T.; Yamada, M.; Akutsu, H.; Kuji, N.; Mochimaru, Y.; Takano, M.; Toyoda, M.; Miyado, K.; Umezawa, A.; Yoshimura, Y. What can we learn from gene expression profiling of mouse oocytes? Reproduction 2008, 135, 581-592.

90. Houmard, B.; Small, C.; Yang, L.; Naluai-Cecchini, T.; Cheng, E.; Hassold, T.; Griswold, M. Global gene expression in the human fetal testis and ovary. Biol. Reprod. 2009, 81, 438-443.

91. Wang, S.; Kou, Z.; Jing, Z.; Zhang, Y.; Guo, X.; Dong, M.; Wilmut, I.; Gao, S. Proteome of mouse oocytes at different developmental stages. Proc. Natl. Acad. Sci. USA 2010, 107, 17639-17644.

92. Zeng, F.; Baldwin, D.A.; Schultz, R.M. Transcript profiling during preimplantation mouse development. Dev. Biol. 2004, 272, 483-496.

93. Tease, C.; Fisher, G. The influence of maternal age on radiation-induced chromosome aberrations in mouse oocytes. Mutat. Res. 1991, 262, 57-62.

94. Barber, R.C.; Dubrova, Y.E. The offspring of irradiated parents, are they stable? Mutat. Res. 2006, 598, 50-60.

95. Luning, K.G.; Frolen, H.; Nilsson, A. Genetic effects of $239 \mathrm{Pu}$ salt injections in male mice. Mutat. Res. 1976, 34, 539-542.

96. Dubrova, Y.E.; Plumb, M.; Brown, J.; Boulton, E.; Goodhead, D.; Jeffreys, A.J. Induction of minisatellite mutations in the mouse germline by low-dose chronic exposure to gamma-radiation and fission neutrons. Mutat. Res. 2000, 453, 17-24.

97. Vorobtsova, I.E. Irradiation of male rats increases the chromosomal sensitivity of progeny to genotoxic agents. Mutagenesis 2000, 15, 33-38.

98. Shiraishi, K.; Shimura, T.; Taga, M.; Uematsu, N.; Gondo, Y.; Ohtaki, M.; Kominami, R.; Niwa, O. Persistent induction of somatic reversions of the pink-eyed unstable mutation in F1 mice born to fathers irradiated at the spermatozoa stage. Radiat. Res. 2002, 157, 661-667. 
99. Barber, R.; Plumb, M.A.; Boulton, E.; Roux, I.; Dubrova, Y.E. Elevated mutation rates in the germ line of first- and second-generation offspring of irradiated male mice. Proc. Natl. Acad. Sci. USA 2002, 99, 6877-6882.

100. Spears, N. In-vitro growth of oocytes. In-vitro growth of ovarian oocytes. Hum. Reprod. 1994, 9 , 969-970.

101. Zhang, L.; Jiang, S.; Wozniak, P.J.; Yang, X.; Godke, R.A. Cumulus cell function during bovine oocyte maturation, fertilization, and embryo development in vitro. Mol. Reprod. Dev. 1995, 40, $338-344$.

102. Hartshorne, G.M.; Barlow, A.L.; Child, T.J.; Barlow, D.H.; Hulten, M.A. Immunocytogenetic detection of normal and abnormal oocytes in human fetal ovarian tissue in culture. Hum. Reprod. 1999, 14, 172-182.

103. Wright, C.S.; Hovatta, O.; Margara, R.; Trew, G.; Winston, R.M.; Franks, S.; Hardy, K. Effects of follicle-stimulating hormone and serum substitution on the in-vitro growth of human ovarian follicles. Hum. Reprod. 1999, 14, 1555-1562.

104. Roig, I.; Garcia, R.; Robles, P.; Cortvrindt, R.; Egozcue, J.; Smitz, J.; Garcia, M. Human fetal ovarian culture permits meiotic progression and chromosome pairing process. Hum. Reprod. 2006, 21, 1359-1367.

105. Brieno-Enriquez, M.A.; Robles, P.; Garcia-Cruz, R.; Roig, I.; Cabero, L.; Martinez, F.; Garcia Caldes, M. A new culture technique that allows in vitro meiotic prophase development of fetal human oocytes. Hum. Reprod. 2010, 25, 74-84.

106. Brieno-Enriquez, M.A.; Robles, P.; Camats-Tarruella, N.; Garcia-Cruz, R.; Roig, I.; Cabero, L.; Martinez, F.; Caldes, M.G. Human meiotic progression and recombination are affected by bisphenol a exposure during in vitro human oocyte development. Hum. Reprod. 2011, 26, 2807-2818.

107. Guerquin, M.J.; Duquenne, C.; Coffigny, H.; Rouiller-Fabre, V.; Lambrot, R.; Bakalska, M.; Frydman, R.; Habert, R.; Livera, G. Sex-specific differences in fetal germ cell apoptosis induced by ionizing radiation. Hum. Reprod. 2009, 24, 670-678.

108. Le Bouffant, R.; Guerquin, M.J.; Duquenne, C.; Frydman, N.; Coffigny, H.; Rouiller-Fabre, V.; Frydman, R.; Habert R.; Livera, G. Meiosis initiation in the human ovary requires intrinsic retinoic acid synthesis. Hum. Reprod. 2010, 25, 2579-2590.

109. Brieno-Enriquez, M.A.; Reig-Viader, R.; Cabero, L.; Toran, N.; Martinez, F.; Roig, I.; Garcia Caldes, M. Gene expression is altered after bisphenol a exposure in human fetal oocytes in vitro. Mol. Hum. Reprod. 2012, 18, 171-183.

110. Brieño-Enriquez, M.A.; Reis, F.; Toran, N.; Cabero L.; Garcia, F.; Ruiz-Herrera, A.; Garcia-Caldés, M.G. Universitat Autònoma de Barcelona, Barcelona, Spain. Unpublished work, 2012.

(C) 2012 by the authors; licensee MDPI, Basel, Switzerland. This article is an open access article distributed under the terms and conditions of the Creative Commons Attribution license (http://creativecommons.org/licenses/by/3.0/). 